\title{
Penentuan Target Pajak Kendaraan Bermotor di Provinsi Bali Menggunakan ARIMA dan Algoritma Genetik
}

\author{
I Gusti Ngurah Rai Dharma Widhura ${ }^{1}$, Rukmi Sari Hartati ${ }^{2}$, Made Sudarma ${ }^{3}$
}

\begin{abstract}
Bali Regional Income Board is a regional organization tasked with determining the amount of local tax revenue target for the next fiscal year. Currently, it is calculated manually in accordance to trends from previous years. It needs to be measured and forecasted accurately. Recent studies shows that forecasting by combining conventional and artificial intelligence (hybrid) methods results in better forecasting accuracy. By that reason, the writer tries to forecast the target of revenue from Motor Vehicle Tax (PKB and BBNKB), which contribute $70 \%$ to Bali Province income by combining ARIMA and Genetic Algorithm. The data used consisted of five groups: yearly and new Vehicles that have linear data types, and as Reverse Names, Entrance Mutations and Output Mutations that have non-linear data types. Each data group consisted of PKB and BBNKB, where it's monthly realization data from 2011 to 2016 used to be training data and realization data for 2017 as test data. The Combined forecasting mechanism is performed using ARIMA to forecast linear data and using Genetic Algorithms for non-linear data.
\end{abstract}

As a benchmark for forecasting using ARIMA and Genetic Algorithms, forecasting using ARIMA and Genetic Algorithms independently is used for all data types (linear and nonlinear). Testing is done by comparing data of forecasting result with that 3 different methods for year 2017 with data realization year 2017 . Then the error percentage is counted using MAPE. From the test results obtained for ARIMA MAPE value of 3,63\%, Genetic Algorithm 2,71\% and combined ARIMA and Genetic Algorithm of $2,34 \%$. Thus, the result of forecasting with combination ARIMA and Genetic Algorithm have the best result and then used to forecasting target of PKB for 2018.

Intisari- Badan Pendapatan Daerah Provinsi Bali merupakan Organisasi Perangkat Daerah yang bertugas melakukan penentuan besaran target penerimaan pajak daerah untuk tahun anggaran selanjutnya. Saat ini masih dilakukan secara manual sesuai dengan tren peningkatan yang ada dari tahun - tahun sebelumnya. Sehingga perlu dilakukan peramalan yang terukur dan akurat. Dalam beberapa penelitian terkini, menunjukkan bahwa peramalan dengan menggabungkan metode konvensional dan kecerdasan buatan (hybrid) menghasilkan tingkat akurasi peramalan yang lebih baik. Untuk itu penulis mencoba untuk melakukan peramalan target penerimaan dari Pajak Kendaraan Bermotor (PKB dan BBNKB), yang menyumbang $70 \%$ terhadap PAD Povinsi Bali dengan menggabungkan metode ARIMA dan Algoritma Genetik.

\footnotetext{
${ }^{1}$ Mahasiswa, Program Studi Magister Teknik Elektro, Badan Pendapatan Daerah Provinsi Bali, Jalan Cok Agung Tresna Nomor 14 Renon, Denpasar Bali INDONESIA (tlp: (0361 222642); fax (0361 - 263225) hp : 0852333081999; e-mail: raiwidhura@gmail.com)

${ }^{2,3}$ Dosen, Program Studi Magister Teknik Elektro, Jalan Panglima Besar Sudirman, Denpasar Bali Indonesia (tlp: 0361239599; fax: 0361-239599; e-mail: rukmisari@unud.ac.id, msudarma@unud.ac.id)
}

Data yang digunakan terdiri dari lima kelompok yaitu Pengesahan dan Kendaraan Baru yang memiliki tipe data linear, serta Balik Nama, Mutasi Masuk dan Mutasi Keluar yang memiliki tipe data non linier. Setiap kelompok data terdiri dari PKB dan BBNKB dimana digunakan data realisasi perbulan dari tahun 2011 sampai dengan 2016 sebagai data training dan realisasi tahun 2017 sebagai data uji. Mekanisme peramalan Gabungan ini dilakukan menggunakan ARIMA untuk meramalkan data linier serta menggunakan Algoritma Genetik untuk data non linier.

Sebagai pembanding untuk peramalan gabungan menggunakan ARIMA dan Algoritma Genetik, dilakukan peramalan menggunakan ARIMA dan Algoritma Genetik secara mandiri untuk semua tipe data (linier dan non linier). Pengujian dilakukan dengan membandingkan data hasil peramalan dengan 3 metode tersebut untuk tahun 2017 dengan data realisasi tahun 2017. Untuk kemudian dihitung persentase kesalahannya menggunakan MAPE. Dari hasil pengujian diperoleh hasil untuk ARIMA nilai MAPE sebesar 3,63\%, Algoritma Genetik 2,71\% serta gabungan ARIMA dan Algoritma Genetik sebesar 2,34\%. Sehingga dengan demikian hasil peramalan dengan gabungan ARIMA dan Algoritma Genetik memiliki hasil terbaik dan selanjutnya digunakan untuk melakukan peramalan untuk menentukan target penerimaan PKB tahun 2018.

Kata Kunci - Peramalan, ARIMA, Algoritma Genetik, Gabungan ARIMA dan Algoritma Genetik, MAPE, penetuan target.

\section{PENDAHULUAN}

Kebijakan dalam penyusunan Rencana Anggaran Pendapatan Belanja Daerah (RAPBD) harus memperhatikan kondisi dan potensi yang dimiliki suatu daerah sesuai dengan kewenangan. Dengan demikian pemerintah daerah dapat merencanakan anggaran pendapatan sendiri dengan kebijakan dan aspirasi daerah berdasarkan potensi riil yang dimiliki.

Saat ini Sumber penerimaan yang dominan memberikan kontribusi pada Pendapatan Asli Daerah (PAD) Provinsi Bali Tahun 2014 adalah Pajak Daerah. Pajak Daerah terdiri dari Pajak Kendaraan Bermotor (PKB), Bea Balik Nama Kendaraan Bermotor (BBNKB), Pajak Bahan Bakar Kendaraan Bermotor (PBBKB), Pajak Air Permukaan (AP) dan Pajak Rokok [1]. Pajak Daerah tersebut di atas berkontribusi sebesar $86,45 \%$ terhadap PAD Provinsi Bali, dimana, rincian kontribusi terhadap $\mathrm{PAD}$ adalah $\mathrm{PKB}$ : 29,45\%, BBNKB : 40,75\%, disusul oleh PBBKB : 11,99\%, Pajak Air Permukaan : 0,06\% dan Pajak Rokok : 4,19\%. Dari data di atas, pajak yang berhubungan dengan kendaraan bermotor (PKB dan BBNKB) memberikan kontribusi $70.20 \%$ terhadap PAD Provinsi Bali dari Pajak Daerah [2]. 
Dinas Pendapatan Provinsi Bali merupakan Satuan Kerja Perangkat Daerah yang bertugas melakukan pemungutan pajak daerah yang menjadi kewenangan Provinsi Bali sehingga juga bertugas menentukan besaran target penerimaan pajak daerah untuk tahun anggaran selanjutnya [3]. Dari penelitian awal penulis di Dinas Pendapatan Provinsi Bali, dalam menentukan target PAD untuk Provinsi Bali, masih dilakukan secara manual berdasarkan data capaian/realisasi tahun terakhir ditambah dengan besaran persentase yang diperkirakan akan dicapai sesuai dengan tren peningkatan yang ada dari tahun - tahun sebelumnya. Padahal adanya perkiraan penerimaan tahun kedepan yang akurat merupakan syarat utama dalam penyusunan RAPBD. Perkiraaan atau dalam hal ini peramalan (forecasting) adalah suatu proses untuk melakukan perkiraan terhadap kondisi dan data di masa depan berdasarkan data masa lalu dan saat ini dan analisis terhadap perkembangan (trend) yang ada [4].

Metode peramalan berdasarkan teknik penerapannya secara umum dibagi menjadi 2 (dua) pendekatan yaitu secara konvensional yang menggunakan perhitungan matematika serta menggunakan metode yang berdasarkan kecerdasan buatan [5]. Masing - masing metode ini memiliki kelebihan. Metode konvensional, seperti misalnya ARIMA memiliki keunggulan dalam peramalan jangka pendek serta data uji yang linier [6]. Sedangkan metode yang berdasarkan kecerdasan buatan, seperti misalnya Algoritma Genetik memiliki kemampuan untuk melakukan peramalan dalam jangka waktu yang pendek maupun panjang serta data yang linier maupun nonlinier [7]. Dalam beberapa penelitian terkini, menunjukkan bahwa peramalan dengan menggabungkan metode konvensional dan kecerdasan buatan (hybrid) menghasilkan tingkat akurasi peramalan yang lebih baik [8], [9], [10], [11],[12].

Melihat kondisi diatas, penulis berpendapat bahwa penghitungan target penerimaan dapat dilakukan dengan lebih terukur menggunakan metode yang sudah teruji sehingga penentuan target PKB dan BBNKB yang berkontribusi sebesar 70,2\% terhadap pajak daerah dapat memberikan gambaran yang lebih riil. Oleh karena itu, penulis mencoba untuk melakukan peramalan target penerimaan dari PKB dan BBNKB untuk tahun selanjutnya menggunakan penggabungan metode (hybrid) [13], [14], yaitu ARIMA dan Algoritma Genetik serta untuk mengetahui akurasi dari peramalan menggunakan kombinasi antara metode ARIMA dan Algoritma Genetik dibandingkan dengan peramalan menggunakan ARIMA dan Algoritma Genetik secara tersendiri

Penelitian ini menggunakan alat ukur Mean Absolute Percentage Error (MAPE). Dalam melakukan pengujian, hasil peramalan tahun 2017 akan dibandingkan dengan data realisasi tahun 2017. Sedangkan data per bulan dari tahun 2011 sampai dengan 2016 sebagai dasar dalam menentukan formula perhitungan. Batas kewajaran persentase MAPE sebesar 10\% [15], [16], [17].
Data dikumpulkan dan dilakukan analisa kebutuhan untuk mengidentifikasi jenis informasi apa saja yang diperlukan. Dalam proses ini meliputi koleksi data pada database SAMSAT Bali melalui proses query yang dilakukan oleh penulis. Data hasil query diklasifikasikan berdasarkan jenis transaksi. Pada Tabel 1, dapat dilihat total perolehan transaksi SAMSAT diseluruh Bali selama periode 2011 sampai dengan 2017.

TABEL I

REKAPITULASI PER TRANSAKSI TAHUN 2011 SAMPAI 2017

\begin{tabular}{|r|l|r|r|}
\hline NO & \multicolumn{1}{|c|}{ NAMA TRANSAKSI } & TOTAL & $\begin{array}{r}\text { PERSEN } \\
\text { TASE }\end{array}$ \\
\hline 1 & Balik Nama & 39.097 .811 .758 & 0,29 \\
\hline 2 & Warisan & 7.332 .100 & 0,00 \\
\hline 3 & Mutasi Masuk Antar Samsat & 8.595 .282 .806 & 0,07 \\
\hline 4 & STNK Rusak / Hilang & 10.036 .829 .700 & 0,11 \\
\hline 5 & Ganti Alamat & 208.360 .300 & 0,00 \\
\hline 6 & Rubah Bentuk & 2.394 .741 .900 & 0,03 \\
\hline 7 & Ganti No. Polisi & 39.007 .131 .641 & 0,41 \\
\hline 8 & Pengesahan STNK setiap tahun & 2.545 .667 .412 .656 & 28,71 \\
\hline 9 & Pengesahan STNK 5 tahun & 429.724 .776 .156 & 4,14 \\
\hline 10 & Ganti Warna Kendaraan & 4.886 .439 .100 & 0,05 \\
\hline 11 & Rubah Sifat & 505.376 .900 & 0,01 \\
\hline 12 & Ganti Nama & 62.313 .800 & 0,00 \\
\hline 13 & Mutasi Ke Luar Daerah & 23.656 .271 .002 & 0,18 \\
\hline 14 & Mutasi Masuk Antar Provinsi & 80.174 .701 .710 & 0,87 \\
\hline 15 & Pendaftaran Kendaraan Baru & 5.546 .460 .062 .225 & 65,13 \\
\hline 16 & Ganti Mesin & 16.950 .000 & 0,00 \\
\hline 17 & Pendaftaran Kendaraan Khusus & 676.357 .900 & 0,01 \\
\hline & TOTAL & $\mathbf{8 . 7 3 1 . 1 7 8 . 1 5 1 . 6 5 4}$ & $\mathbf{1 0 0}$ \\
\hline
\end{tabular}

Jika dilihat persentase transaksi terhadap nilai total pada data Tabel 1 di atas, maka diperoleh 10 (sepuluh) transaksi yang memiliki persentase tertinggi. 10 (sepuluh) transaksi ini dapat diklasifikasikan menjadi 5 (lima) kelompok variabel data yaitu ;

1. Pengesahan (Pengesahan STNK setiap tahun dan pengesahan STNK 5 Tahun)

2. Kendaraan baru (Pendaftaran kendaraan baru)

3. Mutasi Masuk (Mutasi Masuk Antar Samsat dan Mutasi Masuk Antar Provinsi)

4. Mutasi Keluar Daerah

5. Balik Nama (Balik Nama, STNK Rusak/hilang, Ganti No Polisi, Ganti Warna Kendaraan)

Data 1 dan 2 merupakan tipe data yang linier sedangkan 3, 4 dan 5 merupakan tipe data non linier.

Dari 5 (lima) vaiabel di atas, dilakukan koleksi data perbulan dari tahun 2011 sampai tahun 2016 yang akan digunakan sebagai data training untuk menentukan formula peramalan. Pada Tabel 2 dan Tabel 3 merupakan salah satu contoh data dari 5 (lima) kelompok variabel diatas.

\section{Metode Penelitian}

\section{A. Analisa Kebutuhan dan Pengumpulan Data}


Majalah Ilmiah Teknologi Elektro, Vol. 17, No. 3, September - Desember 2018

DOI: https://doi.org/10.24843/MITE.2018.v17i03.P07

TABEL II

DATA KENDARAAN BARU (BBNKB) PER BULAN 2011 - 2013

\begin{tabular}{|r|l|c|c|r|}
\hline \multirow{2}{*}{ NO } & \multirow{2}{*}{ TAHUN/ BULAN } & $\mathbf{2 0 1 1}$ & $\mathbf{2 0 1 2}$ & \multicolumn{1}{c|}{$\mathbf{2 0 1 3}$} \\
\cline { 3 - 5 } & & BBNKB & BBNKB & \multicolumn{1}{c|}{ B BNKB } \\
\hline 1 & JANUARI & 44.697 .086 .300 & 73.155 .185 .400 & 100.740 .615 .000 \\
\hline 2 & FEBRUARI & 42.928 .585 .700 & 68.338 .307 .000 & 98.569 .125 .000 \\
\hline 3 & MARET & 43.349 .301 .500 & 73.921 .952 .300 & 75.421 .050 .000 \\
\hline 4 & APRIL & 45.487 .970 .500 & 73.226 .871 .200 & 104.251 .770 .000 \\
\hline 5 & MEI & 61.100 .120 .200 & 83.261 .031 .000 & 95.465 .340 .000 \\
\hline 6 & JUNI & 63.045 .332 .100 & 85.245 .012 .800 & 92.101 .245 .000 \\
\hline 7 & JULI & 65.520 .573 .600 & 90.773 .302 .500 & 120.745 .980 .000 \\
\hline 8 & AGUSTUS & 72.954 .370 .400 & 69.864 .459 .800 & 84.417 .330 .000 \\
\hline 9 & SEPTEMBER & 60.655 .524 .400 & 83.290 .021 .600 & 101.876 .490 .000 \\
\hline 10 & OKTOBER & 70.693 .331 .100 & 91.087 .320 .000 & 102.466 .455 .000 \\
\hline 11 & NOPEMBER & 69.932 .979 .500 & 85.136 .100 .000 & 94.077 .870 .000 \\
\hline 12 & DESEMBER & 69.090 .214 .900 & 81.617 .160 .000 & 93.484 .950 .000 \\
\hline & TOTAL & 709.455 .390 .200 & 958.916 .723 .600 & 1.163 .618 .220 .000 \\
\hline
\end{tabular}

TABEL III

DATA KENDARAAN BARU (BBNKB) PER BULAN 2014 -2016

\begin{tabular}{|c|l|r|c|c|}
\hline \multirow{2}{*}{ NO } & \multirow{2}{*}{ TAHUN/ B ULAN } & $\mathbf{2 0 1 4}$ & $\mathbf{2 0 1 5}$ & $\mathbf{2 0 1 6}$ \\
\cline { 3 - 5 } & & $\mathbf{B B N K B}$ & $\mathbf{B ~ B N K B}$ & $\mathbf{B}$ B NKB \\
\hline 1 & JANUARI & 100.505 .115 .000 & 96.850 .065 .000 & 83.253 .825 .000 \\
\hline 2 & FEBRUARI & 105.101 .475 .000 & 83.184 .750 .000 & 72.466 .695 .000 \\
\hline 3 & MARET & 104.071 .935 .000 & 93.598 .560 .000 & 79.731 .315 .000 \\
\hline 4 & APRIL & 97.790 .055 .000 & 93.666 .195 .000 & 75.249 .705 .000 \\
\hline 5 & MEI & 84.054 .315 .000 & 78.829 .170 .000 & 87.205 .740 .000 \\
\hline 6 & JUNI & 106.161 .555 .000 & 90.053 .730 .000 & 84.759 .435 .000 \\
\hline 7 & JULI & 94.251 .630 .000 & 68.846 .295 .000 & 64.498 .770 .000 \\
\hline 8 & AGUSTUS & 90.069 .690 .000 & 81.558 .705 .000 & 85.457 .940 .000 \\
\hline 9 & SEPTEMBER & 108.369 .945 .000 & 86.932 .365 .000 & 76.759 .740 .000 \\
\hline 10 & OKTOBER & 105.711 .375 .000 & 85.153 .635 .000 & 79.727 .580 .000 \\
\hline 11 & NOPEMBER & 92.848 .770 .000 & 82.230 .615 .000 & 84.352 .020 .000 \\
\hline 12 & DESEMBER & 89.412 .990 .000 & 79.614 .420 .000 & 81.052 .920 .000 \\
\hline & TOTAL & 1.178 .348 .850 .000 & 1.020 .518 .505 .000 & 954.515 .685 .000 \\
\hline
\end{tabular}

\section{B. Gambaran Umum Penelitian.}

Data sesuai variabel yang telah ditentukan dilakukan peramalannya oleh aplikasi yang dibangun dan menghasilkan hasil peramalan berdasarkan formulasi metode ARIMA untuk data linier dan Algoritma Genetik untuk data non linier untuk tahun 2017. Hasil peramalan ARIMA untuk data linier dan Algoritma Genetik untuk data non linier lalu digabungkan sehingga diperoleh hasil peramalan gabungan untuk seluruh data liner maupun non linier. Proses peramalan didahului dengan melakukan proses training untuk mengetahui pola peramalan yang sesuai dengan menggunakan data per bulan dan per tahun dari tahun 2011 sampai dengan 2016. Selain itu dilakukan juga peramalan menggunakan seluruh data (linier dan non linier) menggunakan ARIMA dan Algoritma Genetik secara tersendiri dan hasilnya akan dijadikan pembanding untuk hasil peramalan gabungan. Adapun alur penelitian dapat dilihat pada Gambar 1.

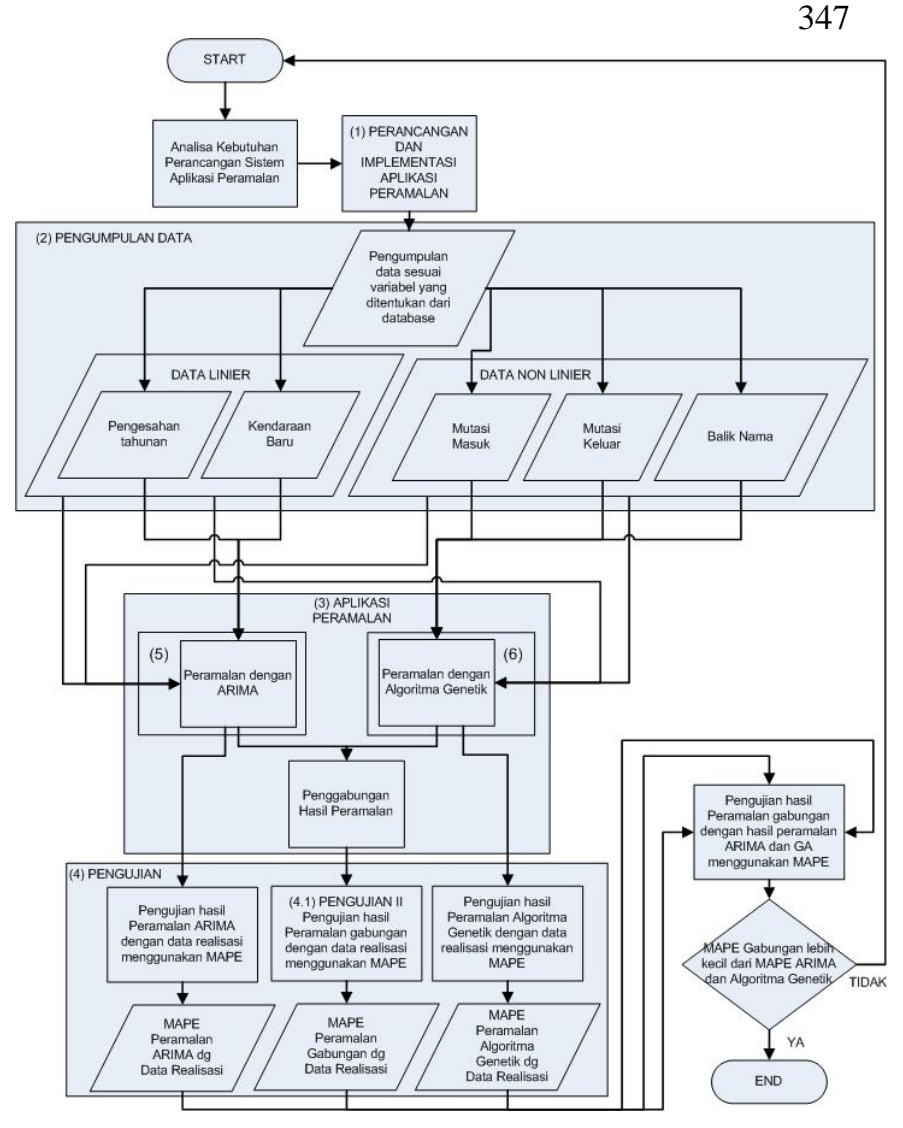

Gambar 1. Diagram Alir Penelitian

\section{Perancangan dan Implementasi Aplikasi Peramalan}

Formula dan variabel data diimplementasikan ke dalam algoritma pemrograman $P H P$. Kemudian melalui antar muka pengguna mengoperasikan aplikasi dan diimplementasikan dalam algoritma pemrograman PHP, HTML, dan CSS. Aplikasi kemudian diuji untuk mengetahui apakah telah menghasilkan keluaran yang diinginkan Alur perancangan dan implementasi dapat dilihat pada Gambar 2.

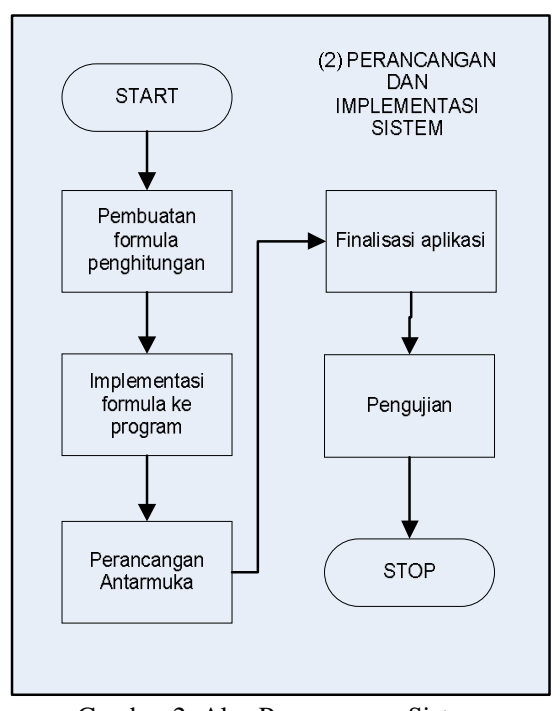

Gambar 2. Alur Perancangan Sistem 


\section{Pengujian Sistem}

Metode pengujian dalam penelitian ini menggunakan MAPE, dimana data hasil peramalan gabungan ARIMA dan Algoritma Genetik dibandingkan dengan hasil realisasi pajak tahun 2017. Batas kewajaran dalam penelitian ini untuk persentase MAPE adalah 10\%, sesuai dengan hasil penelitian - penelitian yang telah disampaikan penulis sebelumnya. Langkah pertama adalah menghitung hasil peramalan dengan realisasi tahun 2017 dan diuji persentase MAPE apakah dibawah $10 \%$ atau tidak. Apabila dibawah 10\% maka selanjutnya akan dihitung pula persentase hasil masing masing peramalan menggunakan ARIMA dan Algoritma Genetik secara tersendiri. Persentasi MAPE untuk ketiga model peramalan ini akan dibandingkan untuk mengetahui hasil MAPE terbaik. Alur pengujian dapat dilihat pada Gambar 3.

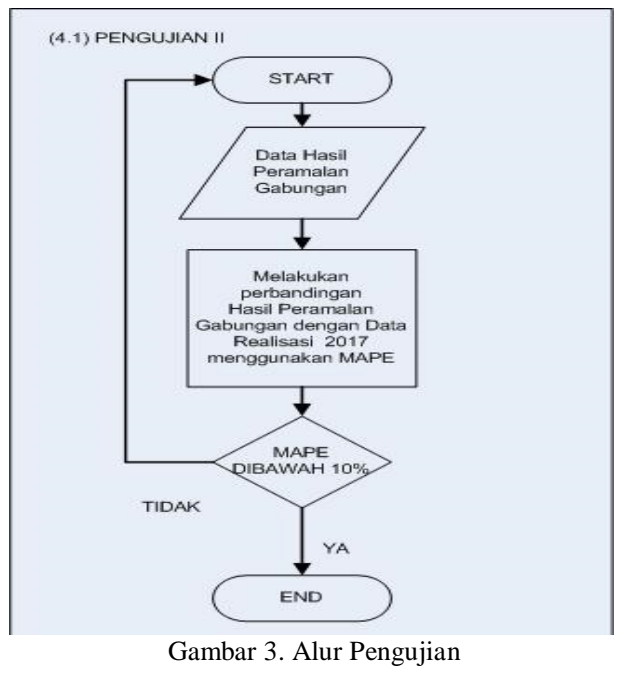

\section{HASIL DAN PEMBAHASAN}

\section{A. Pengujian Hasil Peramalan ARIMA}

Pengujian Peramalan untuk tahun 2017 menggunakan ARIMA dilakukan untuk semua variabel perhitungan yaitu : Pengesahan, Kendaraan Baru, Balik Nama, Mutasi Masuk dan Mutasi Keluar. Hasil dari peramalan ini dibedakan atas PKB dan BBNKB. Kemudian hasil peramalan aplikasi untuk tahun 2017 ini dibandingkan dengan realisasi tahun 2017 untuk semua variabel tersebut, sebagaimana keluaran aplikasi pada Gambar 4 dan Rekapitulasi pada Tabel 4.

\begin{tabular}{|c|c|c|c|c|}
\hline Peramalan A & & & & \\
\hline Peramalan Arim & tuk Tahun 2017 & & & \\
\hline Nama & Peramalan PKB & Peramalan BBNKB & Realisass PKB & Realisasi BBNKB \\
\hline Pengesahan & $961,632,893,730.60$ & - & $1,004,851,195,113.00$ & \\
\hline Mutasi Keluar & $27,650,478,239.00$ & - & 23,749, 454,100.00 & - \\
\hline Mutasi Masuk & $21,490,368,393.80$ & $12,584,260,118.00$ & $22,737,059,357.00$ & $18,964,456,000.00$ \\
\hline Kendaraan Baru & $111,719,859,925.00$ & $1,003,527,743,960.00$ & $115,545,630,525.00$ & $953,133,592,500.00$ \\
\hline Balik Nama & $37,352,042,620.60$ & $9,152,567,550.00$ & $118,716,746,144.00$ & $9,648,525,400.00$ \\
\hline Total & $1,159,845,642,909.00$ & $1,025,264,571,628.00$ & $1,285,600,085,239.00$ & $981,746,573,900.00$ \\
\hline sub Total & & $2,185,110,214,537.00$ & & $2,267,346,659,139.00$ \\
\hline Nilai MAPE & 3.63 & & & \\
\hline
\end{tabular}

Gambar 4. Keluaran Aplikasi untuk Pengujian Peramalan ARIMA
TABEL IV

REKAP HASIL PENGUJIAN PERAMALAN ARIMA

\begin{tabular}{|c|l|r|r|r|}
\hline NO & \multicolumn{1}{|c|}{ TRANSAKSI } & PERAMALAN 2017 & REALISASI 2017 & MAPE \\
\hline 1 & PENGESAHAN & 961.632 .893 .731 & 1.004 .851 .195 .113 & \\
\hline 2 & KENDARAAN BARU & $1.115 .247 .603 .885,00$ & $1.068 .679 .223 .025,00$ & \\
\hline 3 & BALIK NAMA & $46.504 .610 .170,60$ & $128.365 .271 .544,00$ & \\
\hline 4 & MUTASI MASUK & $34.074 .628 .511,80$ & $41.701 .515 .357,00$ & \\
\hline 5 & MUTASI KELUAR & $27.650 .478 .239,00$ & $23.749 .454 .100,00$ & \\
\hline & TOTAL & 2.185 .110 .214 .537 & 2.267 .346 .659 .139 & 3,63 \\
\hline
\end{tabular}

Dari perbandingan hasil peramalan tahun 2017 dengan realisasi tahun 2017, kemudian dihitung persentase tingkat kesalahan dari hasil peramalan tahun 2017 menggunakan MAPE. Diperoleh nilai MAPE sebesar 3,63 persen. Nilai ini termasuk baik dimana toleransi yang digunakan dalam penelitian ini adalah maksimal 10 persen. Grafik perbandingan peramalan dan realisasi dapat dilihat pada Gambar 5.

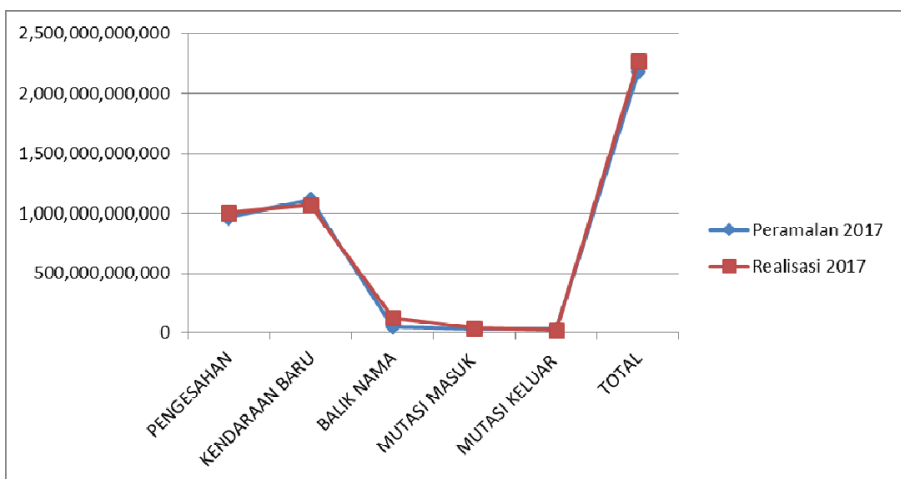

Gambar 5. Grafik Perbandingan Hasil Pengujian Peramalan ARIMA

\section{B. Pengujian Hasil Peramalan Algoritma Genetik}

Pengujian Peramalan untuk tahun 2017 menggunakan Algoritma Genetik dilakukan untuk semua variabel perhitungan yaitu : Pengesahan, Kendaraan Baru, Balik Nama, Mutasi Masuk dan Mutasi Keluar. Hasil dari peramalan ini dibedakan atas PKB dan BBNKB. Kemudian hasil peramalan aplikasi untuk tahun 2017 ini dibandingkan dengan realisasi tahun 2017 untuk semua variabel tersebut, sebagaimana keluaran aplikasi pada Gambar 6 dan Rekapitulasi pada Tabel 5.

\begin{tabular}{|c|c|c|c|c|}
\hline Peramalan & & & & \\
\hline Peramalan GA & Tahun 2017 & & & \\
\hline Nama & Peramalan PKB & Peramalan BENKB & Realisasi PKB & Realisasi BBNKB \\
\hline Pengesanan & 1,108,630,152,924.67 & - & $1,004,851,195,113.00$ & - \\
\hline Mutasi Keluar & $38,604,217,342.50$ & - & $23,749,454,100.00$ & - \\
\hline Mutasi Masuk & $24,385,704,399.00$ & $12,584,260,118.00$ & $22,737,059,357.00$ & $18,954,456,0000.00$ \\
\hline Kendaraan Baru & $108,547,217,670.83$ & $851,469,141,033.00$ & $115,545,630,525.00$ & $953,133,592,5000.00$ \\
\hline Balik Nama & $48,744,870,806.33$ & $13,000,383,558.33$ & $118,716,746,144.00$ & $9,648,525,400.00$ \\
\hline Total & $1,328,912,163,143.33$ & $877,053,784,709.33$ & $1,285,600,085,239.00$ & $981,746,573,900 \cdot .00$ \\
\hline sub Total & & $2,205,965,947,852.67$ & & $2,267,345,659,139.00$ \\
\hline Nilai MAPE & 2.71 & & & \\
\hline
\end{tabular}

Gambar 6. Keluaran Aplikasi untuk Pengujian Peramalan Algoritma Genetik 
TABEL V

REKAP HASIL PENGUJIAN PERAMALAN ALGORITMA GENETIK

\begin{tabular}{|r|l|r|r|r|}
\hline NO & \multicolumn{1}{|c|}{ TRANSAKSI } & PERAMALAN 2017 & \multicolumn{1}{c|}{ REALISASI 2017 } & MAPE \\
\hline 1 & PENGESAHAN & 1.108 .630 .152 .925 & 1.004 .851 .195 .113 & \\
\hline 2 & KENDARAAN BARU & $960.016 .358 .703,83$ & $1.068 .679 .223 .025,00$ & \\
\hline 3 & BALIK NAMA & $61.745 .254 .364,67$ & $128.365 .271 .544,00$ & \\
\hline 4 & MUTASI MASUK & $36.969 .964 .517,00$ & $41.701 .515 .357,00$ & \\
\hline 5 & MUTASI KELUAR & $38.604 .217 .342,50$ & $23.749 .454 .100,00$ & \\
\hline & TOTAL & 2.205 .965 .947 .853 & 2.267 .346 .659 .139 & 2,71 \\
\hline
\end{tabular}

Dari perbandingan hasil peramalan aplikasi untuk tahun 2017 dengan realisasi tahun 2017, kemudian dihitung persentase tingkat kesalahan dari hasil peramalan tahun 2017 menggunakan MAPE. Diperoleh nilai MAPE sebesar 2,71 persen. Nilai ini termasuk baik dimana toleransi yang digunakan dalam penelitian ini adalah maksimal 10 persen. Grafik perbandingan peramalan dan realisasi dapat dilihat pada Gambar 7.

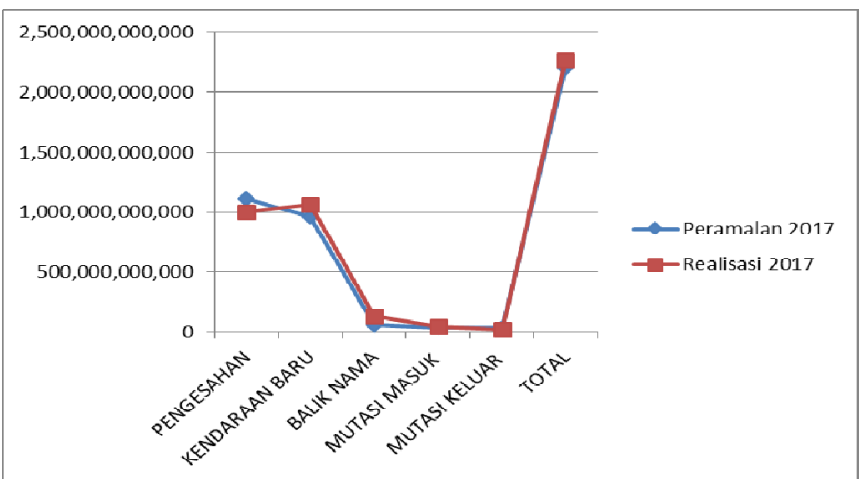

Gambar 7. Grafik Perbandingan Hasil Pengujian Algoritma Genetik

\section{Pengujian Hasil Peramalan Gabungan ARIMA dan} Algoritma Genetik

Pengujian Peramalan untuk tahun 2017 menggunakan Gabungan ARIMA dan Algoritma Genetik dilakukan dengan menyesuaikan metode dengan tipe data variabel yang ada. Untuk Pengesahan dan Kendaraan Baru yang datanya linier dilakukan peramalan dengan menggunakan ARIMA. Hasil dari peramalan ini dibedakan atas PKB dan BBNKB untuk semua variabel tersebut. Sedangkan untuk Balik Nama, Mutasi Keluar dan Mutasi Masuk yang datanya non linier dilakukan peramalan dengan menggunakan Algoritma Genetik. Hasil dari peramalan ini juga dibedakan atas PKB dan BBNKB untuk semua variabel tersebut. Kemudian hasil dari peramalan dengan menggunakan ARIMA dan dengan menggunakan Algoritma Genetik digabungkan sehingga menjadi suatu hasil peramalan Gabungan. Hasil peramalan Gabungan untuk tahun 2017 ini dibandingkan dengan realisasi tahun 2017, sebagaimana keluaran aplikasi pada Gambar 8 dan Rekapitulasi pada Tabel 6.
Peramalan Gabungan

\begin{tabular}{|c|c|c|c|c|}
\hline \multicolumn{5}{|c|}{ Peramalan Gabungan } \\
\hline Nama & Peramalan PKB & Peramalan BENKB & Reallsası PKB & Reallsası। BBNKB \\
\hline Pengesahan & $961,632,893,730.60$ & & 1,004,851, 195, 113.00 & \\
\hline Muasi Kelluar & $38,604,217,342.50$ & & $23,749,454,100.00$ & \\
\hline Mưasi Masuk & $24,385,704,399.00$ & $12,584,260,118.00$ & $22,737,059,357.00$ & $18,964,456,000.00$ \\
\hline Kendaraan Earu & $111,719,859,925.00$ & $1,003,527,743,960.00$ & $115,545,630,525.00$ & $963,133,592,500.00$ \\
\hline Balik Nama & $48,744,870,806.33$ & $13,000,333,558.33$ & $118,716,746,144.00$ & $9,648,525,400.00$ \\
\hline Total & $1,185,007,545,203.43$ & $1,029,112,387,636.33$ & $1,205,600,005,239.00$ & $901,746,573,900.00$ \\
\hline sub Total & & $2,214,199,933.839 .77$ & & $2,267,346,659,139.00$ \\
\hline Nilai MAPE & 2.34 & & & \\
\hline
\end{tabular}

Gambar 8. . Keluaran Aplikasi untuk Pengujian Peramalan Gabungan

TABEL VI

REKAPITULASI HASIL PENGUJIAN PERAMALAN GABUNGAN

\begin{tabular}{|r|l|r|r|r|}
\hline NO & \multicolumn{1}{|c|}{ TRANSAKSI } & PERAMALAN 2017 & \multicolumn{1}{|c|}{ REALISASI 2017 } & MAPE \\
\hline 1 & PENGESAHAN & 961.632 .893 .731 & 1.004 .851 .195 .113 & \\
\hline 2 & KENDARAAN BARU & $1.115 .247 .603 .885,00$ & $1.068 .679 .223 .025,00$ & \\
\hline 3 & BALIK NAMA & $61.745 .254 .364,67$ & $128.365 .271 .544,00$ & \\
\hline 4 & MUTASI MASUK & $36.969 .964 .517,00$ & $41.701 .515 .357,00$ & \\
\hline 5 & MUTASI KELUAR & $38.604 .217 .342,50$ & $23.749 .454 .100,00$ & \\
\hline & TOTAL & 2.214 .199 .933 .840 & 2.267 .346 .659 .139 & 2,34 \\
\hline
\end{tabular}

Dari perbandingan hasil peramalan tahun 2017 dengan realisasi tahun 2017, kemudian dihitung persentase tingkat kesalahan dari hasil peramalan tahun 2017 menggunakan MAPE. Diperoleh nilai MAPE sebesar 2,34 persen. Nilai ini termasuk sangat baik dimana toleransi yang digunakan dalam penelitian ini adalah maksimal 10 persen. Grafik perbandingan peramalan dan realisasi dapat dilihat pada Gambar 9.

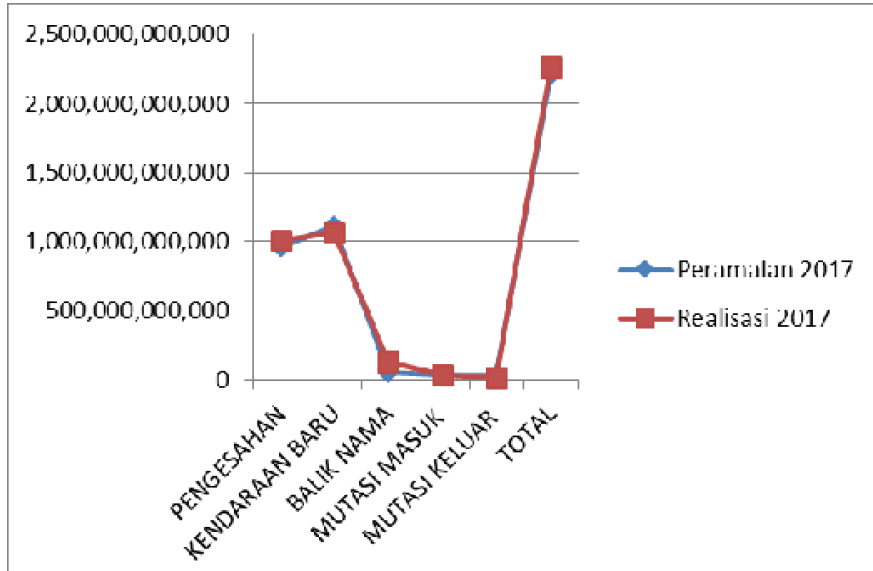

Gambar 9. Grafik Perbandingan Hasil Pengujian Peramalan Gabungan

\section{Perbandingan Hasil Pengujian}

Sesuai hasil pengujian yang dilakukan dengan peramalan menggunakan ARIMA, peramalan menggunakan Algoritma Genetik dan peramalan menggunakan Gabungan ARIMA dan Algoritma Genetik dapat diperoleh hasil perbandingan dengan realisasi tahun 2017 sebagaimana data pada Tabel 7. Grafik perbandingannya dapat dilihat pada Gambar 10. 
TABEL VII

HASIL SELURUH PERAMALAN DAN REALISASI

\begin{tabular}{|c|l|r|r|r|r|}
\hline \multirow{2}{*}{ NO } & \multicolumn{1}{|c|}{ TRANSAKSI } & \multicolumn{1}{c|}{ ARIMA 2017 } & \multicolumn{1}{c|}{$\begin{array}{c}\text { ALGORITMA } \\
\text { GENETIK 2017 }\end{array}$} & \multicolumn{1}{c|}{ GABUNGAN 2017 } & \multicolumn{1}{c|}{ REALISASI 2017 } \\
\hline 1 & PENGESAHAN & 961.632 .893 .731 & 1.108 .630 .152 .925 & 961.632 .893 .731 & 1.004 .851 .195 .113 \\
\hline 2 & KENDARAAN BARU & $1.115 .247 .603 .885,00$ & $960.016 .358 .703,83$ & $1.115 .247 .603 .885,00$ & $1.068 .679 .223 .025,00$ \\
\hline 3 & BALIK NAMA & $46.504 .610 .170,60$ & $61.745 .254 .364,67$ & $61.745 .254 .364,67$ & $128.365 .271 .544,00$ \\
\hline 4 & MUTASI MASUK & $34.074 .628 .511,80$ & $36.969 .964 .517,00$ & $36.969 .964 .517,00$ & $41.701 .515 .357,00$ \\
\hline 5 & MUTASI KELUAR & $27.650 .478 .239,00$ & $38.604 .217 .342,50$ & $38.604 .217 .342,50$ & $23.749 .454 .100,00$ \\
\hline & TOTAL & 2.185 .110 .214 .537 & 2.205 .965 .947 .853 & 2.214 .199 .933 .840 & 2.267 .346 .659 .139 \\
\hline
\end{tabular}

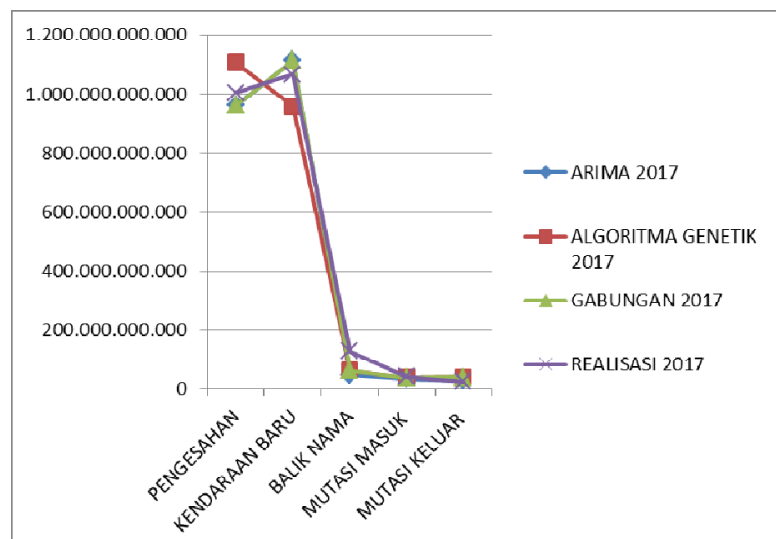

Gambar 10. Hasil Perbandingan seluruh Peramalan dan Realisasi.

Dari data di atas, dapat kita peroleh MAPE hasil seluruh peramalan sehingga dapat diketahui peramalan dengan nilai MAPE terendah, sebagaimana keluaran dari menu Laporan pada aplikasi pada Gambar 11 dan Tabel 8.

\begin{tabular}{|c|c|c|c|}
\hline \multicolumn{4}{|l|}{ Tahun 2017} \\
\hline Algoritma / Metode & Hasil Peramalan & Realisasi & MAPE \\
\hline GA & $2,205,965,947,852.67$ & $2,267,346,659,139.00$ & 2,71 \\
\hline ARIMA & $2,195,111,214,537.00$ & $2,267,345,, 659,139.00$ & 3,63 \\
\hline GAEUNGAN & 2.214 .199 .939 .839 .77 & $2.267 .345,659 \cdot 13900$ & 2,34 \\
\hline
\end{tabular}

Gambar 11. Hasil Perbandingan MAPE seluruh Peramalan

TABEL VIII

PERBANDINGAN MAPE SELURUH PERAMALAN

\begin{tabular}{|c|l|r|}
\hline NO & PERAMALAN 2017 & \multicolumn{2}{|c|}{ MAPE } \\
\hline 1 & ARIMA & 3,63 \\
\hline 2 & ALGORITMA GENETIK & 2,71 \\
\hline 3 & GABUNGAN & 2,34 \\
\hline
\end{tabular}

Dari hasil ini dapat diketahui bahwa peramalan menggunakan Gabungan ARIMA dan Algoritma Genetik memiliki persentase MAPE yang terkecil sehingga merupakan peramalan dengan hasil terbaik pada penelitian ini.

\section{E. Perbandingan Hasil Pengujian Peramalan dengan Target 2017}

Dari hasil pengujian yang dilakukan dapat diketahui bahwa Peramalan Gabungan ARIMA dan Algoritma Genetik memiliki hasil terbaik dalam meramalkan realisasi perolehan untuk tahun 2017. Sesuai dengan salah tujuan penelitian ini yaitu untuk memperoleh metode yang lebih terukur dan riil untuk menentukan target Penerimaan PKB, maka perlu dilakukan perbandingan hasil peramalan Gabungan ARIMA dan Algoritma Genetik untuk tahun 2017 dengan target yang telah ditentukan secara manual untuk tahun 2017, sehingga dapat dilihat performa dari peramalan Gabungan ARIMA dan Algoritma Genetik. Adapun target 2017 dapat dilihat pada Tabel 9.

TABEL IX

TARGET PKB DAN BBNKB 2017

\begin{tabular}{|c|c|c|c|c|c|}
\hline \multicolumn{4}{|c|}{$\begin{array}{c}\text { KODE } \\
\text { REKENING }\end{array}$} & \multirow[t]{2}{*}{ URAIAN PENERIMAAN } & \multirow{2}{*}{$\begin{array}{c}\text { TARGET INDUK } \\
\text { ANGGARAN } 2017 \\
1.185 .517 .000 .000\end{array}$} \\
\hline 4 & & \begin{tabular}{|l|l|}
1 & 01 \\
\end{tabular} & & & \\
\hline 4 & 1 & $\begin{array}{lll}1 & 01 \\
\end{array}$ & 01 & PKB - Mobil Penumpang - Sedan & 40.787.962.905 \\
\hline 4 & 1 & \begin{tabular}{l|l|l}
1 & 01 \\
\end{tabular} & 02 & PKB - Mobil Penumpang - Jeep & 89.576 .858 .148 \\
\hline 4 & 1 & \begin{tabular}{|l|l|}
1 & 01 \\
\end{tabular} & 03 & PKB - Mobil Penumpang - Minibus & 476.426 .203 .634 \\
\hline 4 & 1 & \begin{tabular}{|l|l|}
1 & 01 \\
\end{tabular} & 04 & PKB - Mobil Bus - Microbus & 6.246 .195 .744 \\
\hline 4 & 1 & \begin{tabular}{l|l|}
1 & 01 \\
\end{tabular} & 05 & PKB - Mobil Bus - Bus & 2.281 .497 .940 \\
\hline 4 & 1 & \begin{tabular}{l|l|l|}
1 & 01 \\
\end{tabular} & 06 & PKB - Mobil Barang/Beban - Pick Up & 100.703.306.573 \\
\hline 4 & 1 & \begin{tabular}{|l|l|l|}
1 & 01 \\
\end{tabular} & 07 & PKB - Mobil Barang/Beban - Light Truck & 42.191 .727 .723 \\
\hline 4 & 1 & \begin{tabular}{l|l|}
1 & 01 \\
\end{tabular} & 08 & PKB - Mobil Barang/Beban - Truck & 19.484 .068 .354 \\
\hline 4 & 1 & \begin{tabular}{|l|l|}
1 & 01 \\
\end{tabular} & 09 & PKB - Sepeda Motor - Sepeda Motor Roda 2 & 407.819 .178 .979 \\
\hline 4 & 1 & \begin{tabular}{l|l|l}
1 & 02 \\
\end{tabular} & & Bea Balik Nama Kendaraan Bermotor (BBNKB) & 1.162 .766 .503 .675 \\
\hline 4 & 1 & \begin{tabular}{|l|l|}
1 & 02 \\
\end{tabular} & 01 & BBNKB - Mobil Penumpang - Sedan & 18.299 .278 .799 \\
\hline 4 & 1 & \begin{tabular}{l|l|}
1 & 02 \\
\end{tabular} & 02 & BBNKB - Mobil Penumpang - Jeep & 55.804 .358 .802 \\
\hline 4 & 1 & \begin{tabular}{l|l|l|}
1 & 02 \\
\end{tabular} & 03 & BBNKB - Mobil Penumpang - Minibus & 475.570 .004 .743 \\
\hline 4 & 1 & \begin{tabular}{|l|l|}
1 & 02 \\
\end{tabular} & 04 & BBNKB - Mobil Bus - Microbus & 13.218 .392 .802 \\
\hline 4 & 1 & \begin{tabular}{|l|l|l|l|l|l|}
1 & 02 \\
\end{tabular} & 05 & BBNKB - Mobil Bus - Bus & 3.132 .306 .872 \\
\hline 4 & 1 & \begin{tabular}{l|l|l|l|l}
1 & 02 & 1 \\
\end{tabular} & 06 & BBNKB - Mobil Barang/Beban - Pick Up & 93.620 .621 .105 \\
\hline 4 & 1 & \begin{tabular}{|l|l|}
1 & 02 \\
\end{tabular} & 07 & BBNKB - Mobil Barang/Beban - Light Truck & 30.773 .776 .184 \\
\hline 4 & 1 & 102 & 08 & BBNKB - Mobil Barang/Beban - Truck & 17.540 .583 .848 \\
\hline 4 & & \begin{tabular}{|l|l|}
1 & 02 \\
\end{tabular} & 09 & BBNKB - Sepeda Motor - Sepeda Motor Roda 2 & 454.807 .180 .520 \\
\hline & & & & TOTAL & 2.348.283.503.675 \\
\hline
\end{tabular}

Target di atas dibagi berdasarkan rekening pada Kas Daerah Pemerintah Provinsi Bali sesuai dengan jenis kendaraan bermotor yang ada. Dari hasil perbandingan target 2017 dengan realisasi tahun 2017, kemudian dihitung persentase tingkat kesalahan dari hasil peramalan tahun 2017 menggunakan MAPE, diperoleh nilai MAPE sebesar 3,57 persen. Perbandingan hasil peramalan Gabungan, Target 2017 dan realisasi 2017 dapat dilihat pada Tabel 10 dan Gambar 11.

TABEL $X$

TARGET 2017, PERAMALAN GABUNGAN DAN REALISASI 2017
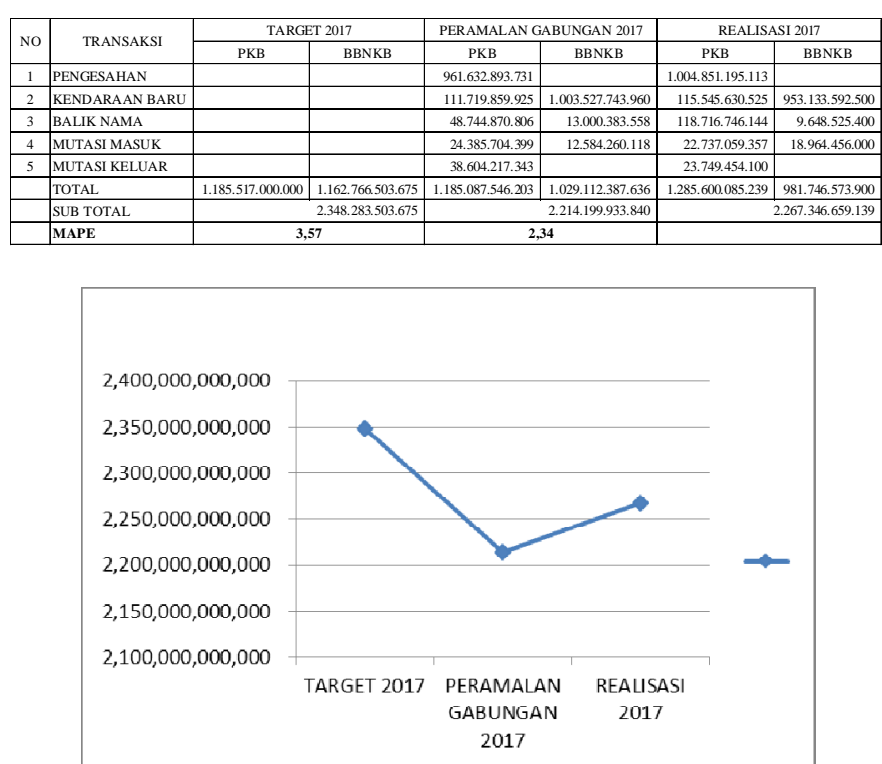

Gambar 11. Perbandingan Target 2017, Peramalan dan Realisasi 2017

Dari data tersebut diatas dapat diketahui bahwa hasil peramalan Gabungan lebih baik dari target yang telah ditentukan secara manual untuk tahun 2017 jika dibandingkan dengan realisasi tahun 2017. 


\section{F. Peramalan untuk menentukan Target PKB}

Sesuai dengan hasil Pengujian, peramalan menggunakan Gabungan ARIMA dan Algoritma Genetik memiliki persentase kesalahan yang terkecil. Hal ini sesuai dengan apa yang menjadi asumsi awal dalam penelitian ini. Untuk itu selanjutnya akan dilakukan peramalan untuk tahun 2018 dengan menggunakan Gabungan ARIMA dan Algoritma Genetik. Adapun hasil peramalan aplikasi untuk tahun 2018 dapat dilihat pada Gambar 12 serta Tabel 11.

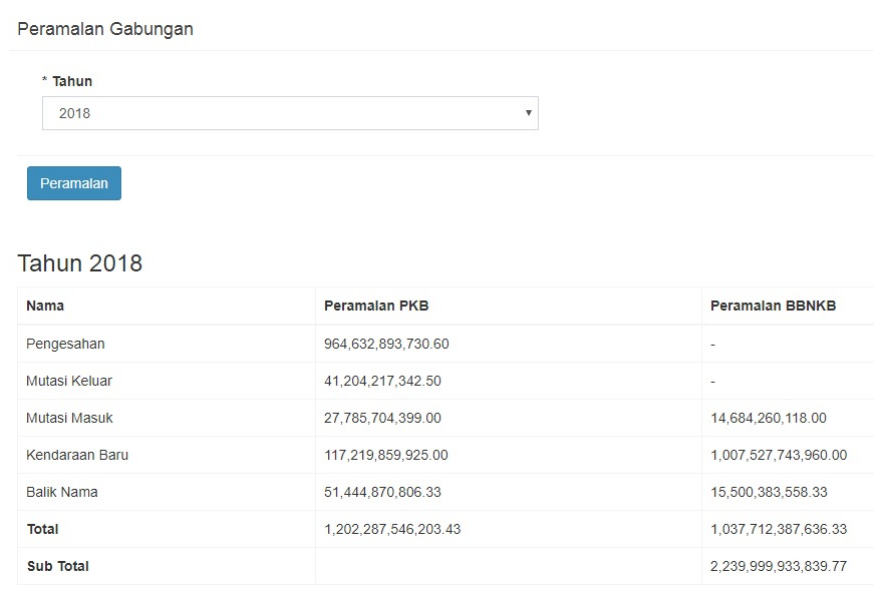

Gambar 12. Hasil Peramalan Gabungan Tahun 2018

TABEL XI

HASIL PERAMALAN GABUNGAN TAHUN 2018

\begin{tabular}{|r|l|r|r|}
\hline \multirow{2}{*}{ NO } & \multirow{2}{*}{ TRANSAKSI } & \multicolumn{2}{|c|}{ PERKIRAAN TARGET UNTUK TAHUN 2018 } \\
\cline { 3 - 4 } & & \multicolumn{1}{|c|}{ PKB } & \multicolumn{1}{c|}{ BBNKB } \\
\hline 1 & PENGESAHAN & 964.632 .893 .731 & \\
\hline 2 & KENDARAAN BARU & $117.219 .859 .925,00$ & $1.007 .527 .743 .960,00$ \\
\hline 3 & BALIK NAMA & 51.444 .870 .806 & 15.500 .383 .558 \\
\hline 4 & MUTASI MASUK & 27.785 .704 .399 & 14.684 .260 .118 \\
\hline 5 & MUTASI KELUAR & 41.204 .217 .342 & \\
\hline & TOTAL & 1.202 .287 .546 .203 & 1.037 .712 .387 .636 \\
\hline & SUB TOTAL & \multicolumn{3}{|c}{2.239 .999 .933 .839} \\
\hline
\end{tabular}

\section{KESIMPULAN}

Kesimpulan yang dapat ditarik dari penelitian ini adalah sebagai berikut :

1. Penentuan Target Penerimaan PKB di Provinsi Bali dilakukan dengan menggunakan metode peramalan yang terbaik diantara peramalan menggunakan ARIMA, Algoritma Genetik dan Gabungan ARIMA dan Algoritma Genetik.

2. Untuk menentukan yang terbaik, dilakukan pengujian peramalan untuk tahun 2017 menggunakan menggunakan ARIMA, Algoritma Genetik dan Gabungan ARIMA dan Algoritma Genetik dengan data perbulan dari tahun 2011 sampai dengan 2016 sebagai data training. Dari hasil pengujian diperoleh nilai MAPE peramalan untuk tahun 2017 menggunakan ARIMA sebesar 3,63 persen, nilai MAPE peramalan untuk tahun 2017 menggunakan
Algoritma Genetik sebesar 2,71 persen dan nilai MAPE peramalan untuk tahun 2017 menggunakan Gabungan ARIMA dan Algoritma Genetik sebesar 2,34 persen.

3. Demikian juga jika dibandingkan dengan target yang telah ditentukan secara manual untuk tahun 2017, dimana memiliki nilai MAPE sebesar 3,57 persen berbanding dengan nilai MAPE sebesar 2,34 persen milik Peramalan Gabungan ARIMA dan Algoritma Genetik.

4. Dengan demikian maka peramalan menggunakan Gabungan ARIMA dan Algoritma Genetik adalah yang memberikan hasil yang terbaik sehingga selanjutnya digunakan untuk melakukan Penentuan Target Penerimaan Pajak Kendaraan Bermotor di Provinsi Bali untuk tahun 2018.

5. Namun demikian, nilai MAPE yang diperoleh walaupun telah memenuhi target yang diharapkan, masih memiliki selisih nominal yang cukup besar, sehingga kiranya diperlukan adanya teknik peramalan yang lain untuk digunakan dalam kasus ini sehingga diperoleh hasil peramalan yang lebih baik dengan selisih nominal yang lebih kecil

\section{REFERENSI}

[1] Peraturan Daerah Bali Nomor 1 Tahun 2011 tentang Pajak Daerah.

[2] Buku Pendapatan Daerah Provinsi Bali, 2014, Dinas Pendapatan Daerah Provinsi Bali.

[3] Peraturan Gubernur Bali Nomor 68 Tahun 2011 Tentang Rincian Tugas Pokok Dinas Pendapatan Provinsi Bali.

[4] Makridakis, S, Wheelwright,S.C. \& Hyndman, R.J (1998), Forecasting: Methods and Application, $3^{\text {rd }}$ edition, John Wiley \& Sons, New York.

[5] Khatoon, Shahida, Ibraheem, Arumesh Kr. Singh, Priti, 2014. Judul jurnal : Analysis and Comparison of Various Methods Available for Load Forecasting : An Overview.

[6] Zhang, Honyu, 2008. Judul Jurnal : An initial sudy of Growth of Eclipse Defect.

[7] K. Karabulata, A. Alkanb,dan A.S Yilmaz. 2008. Judul jurnal : Long term energy consumption forecasting genetic programming.

[8] Chen, Kuan-Yu dan Chen Hua Wang, 2007. Judul jurnal : Support vector regression with Genetic Algorithm in forecasting tourism demand. (Elsevier).

[9] Zheng, Fengxia dan Shouming Zhong, 2011. Judul jurnal : Time series forecasting using an ensemble model incorporating ARIMA and ANN based on combined objectives. (IEEE).

[10] Jayadeep Pati dan K.K Shukla, 2014. Judul jurnal : A Comparison of ARIMA, Neural Network and a Hybrid Technique for Debian Bug Number Prediction. (IEEE).

[11] Imelda Purba, Adhistya Erna Permanasari, Noor Akhmad Setiawan, 2014. Judul jurnal : Optimization of Neural Network Using Genetic Algorithm in Forecasting Third Part Fund Bank. (IEEE).

[12] Joao Fausto Lorenzato de Oliveira, Teresa B Ludermir, 2014. Judul Jurnal : A Distribute PSO-ARIMA-SVR Hybrid System for Time Series Forecasting (IEEE).

[13] Sheng Lu, Zhong-jian Cai dan Xiao-bin Zhang, 2009. Judul Jurnal : Application of GA-SVM Time Series Prediction in Tax Forecasting. (IEEE).

[14] Jose Carlos R. Filho, Carolina M. Affonso, Roberto C.L. Oliveira, 2014. Judul jurnal : Energy Price Forecasting in the North Brazilian Market using NN - ARIMA model and Explanatory Variables. (IEEE).

[15] Dezhi Liu, Rufei Zhang, Juan Li, 2011. Judul jurnal : Tax Revenue Combination Forecast of Hebei Province Based on the IOWA Operator. (IEEE). 
[16] Rubita Sudirman, Dr. Kaveh Ashenayi dan Mostafa Golbaba, 2012. Judul jurnal : Comparison of Methods Used for Forecasting Solar Radiation. (IEEE).

[17] K.M.U Ahmed, M. Amptzis, P.H. Nguyen, W.L. Kling, 2014. Judul jurnal : Application of Time Series and Artificial Neural Network Models in Short term Load Forecasting for Scheduling of Storage Devices. (IEEE). 